DOI: 10.7592/methis.v13i16.12459

\title{
Non tibi per ventos veneranda Poëtica crescit... 1 Johannes Hörnick ja humanistlik poeetikakäsitlus varauusaegses Eestis ${ }^{2}$
}

Kristi Viiding

Sarnaselt paljude kirjandusžanride ja alaliikidega algas luulekunsti teooria ja ajaloo käsitlemine Eesti- ja Liivimaal hilishumanistliku kirjandusdiskursuse raames 17. sajandi avapoolel ladinakeelsete akadeemiliste kõnede ja disputatsioonide vormis. Siinsed kolm ladinakeelset poeetikat on Lääne- ja Kesk-Euroopa renessansiaegsete poeetikate selektiivsed sulamid, mis ammutasid otse või vahendatult ideid ja lähenemisaspekte antiikautorite luule- ja kõnekunsti alastest teoreetilistest tekstidest, peamiselt Horatiuse „Luulekunstist“, aga ka Aristotelese "Poeetikast“, Cicero kõnekunsti alasest kõnest „Poeet Archiase kaitseks“, traktaatidest „Kõnemees“, „Brutus“ jt. Euroopa humanistliku kirjakultuuri kui terviku seisukohast innovatiivseid poeetikaalaseid käsitlusi Eesti- ega Liivimaal ei koostatud ega avaldatud. Siinsed poeetikad on väikese mahu, didaktilise või ülistava lähenemise ja oluliste poleemiliste elementideta. Ent kuna regioonis ei taasavaldatud 17. sajandil ühtki mujal ilmunud luulekunsti alast käsitlust, ${ }^{3}$ siis annavad just kohalikud kompilatiivsed poeetikad ülevaate Eesti- ja Liivimaale jõudnud poeetikateooria elementidest, luule mõistmise, hindamise ja kritiseerimise paradigmast, nagu seda vahendati siinsete õpetatud institutsioonide, s.t ülikooli ja gümnaasiumide juures.

Käesoleva publikatsiooni eesmärk on tuua Eesti kirjandusajaloo ja -teooria uurijateni üks kolmest 17. sajandil regioonis avaldatud poeetikast ja nimelt kronoloogiliselt hiliseim (1671), kuid mahult ulatuslikem: Johannes Hörnicki „Luulekunsti ülistus, esitatud Tallinna gümnaasiumis inauguratsioonikõnes maikuu kalendidel 1671. aastal“. Kommenteeritud tervikeestindusele eelneb sissejuhatav tutvustus regiooni varasematest poeetikaalastest seisukohavõttudest ja trükistest 17. sajandi avapoolel. Nii sissejuhatuses kui ka kommentaaris on tähelepanu

1 Tsitaat Jakob Lotichiuse „Kõnest luulekunsti kohta“: „Auväärne luulekunst ei tule tuulest“ (lad k). Non tibi per ventos veneranda Poëtica crescit / Illa sed assiduo parta labore venit („Auväärt luuletuskunst sinu sülle ei lange ju tuulest,/ kasvab ja küpseb su sees üksnes su vaevas ja töös“). (Lotichius 1642: A4.) Vrd ladina vanasõna Non iacet in molli veneranda scientia lecto / illa sed assiduo parta labore venit („Auväärt oskus ei leba pehmes voodis, vaid tuleb pideva tööga").

2 Artikli valmimist on toetanud Eesti HTM rahvusteaduste baasfinantseerimise grant (PFLGR12915) ning ETF-i grant Balti kirjakultuuri uurimus-ja võrguprojekt EEVA (ETF9178). Tänan kolleeg Kadri Novikovi (Tartu Ülikool) abi eest kreeka autorite eeskujude täpsustamisel.

3 Küll ilmus 1680. aastal Tallinnas Gerhard Johannes Vossiuse retoorikakäsiraamatu lühendatud väljaanne kohaliku gümnaasiumi kõnekunstiõpetuse tarbeks (Vossius [1680]; vt Kaju 2014: 58-59, 127). 
pööratud eelkõige antiigiretseptsiooni ning Euroopa uusladina kirjanduse osale regiooni poeetilise mõtte tekkel, Johannes Hörnicki kõne puhul ka tema leksikaalsele meisterlikkusele. Kõik tõlkekatkendid, kui ei ole märgitud teisiti, pärinevad artikli autorilt.

\section{Ettevalmistavad käsitlused}

Ehkki kõrgemad akadeemilised õppeasutused ja trükikojad rajati Tartusse ja Tallinnasse 1630. aastail, ei jõutud esimesel tegutsemiskümnendil veel iseseisvate luulekunsti teemaliste käsitluste avaldamiseni. Säilinud trükiste põhjal algas poeetikaalane refleksioon kahe Tartu Akadeemia üliõpilase harjutuskõne raames vabade kunstide kohta, millest mõlemas põhjendati lühidalt ka luulekunsti tähtsust ja kasu. 1638. aastal esines Rootsi päritolu üliõpilane Ingemar Petri Smetander ${ }^{4}$ kõnega „Vabade kunstide meeldivusest ja kasulikkusest“:

6. argument luulekunsti õpinguist. Seetõttu on luulekunst see, mis triumfeerigu seni teadmatutel viisidel!

(Põhjendus nr 1). Võistleb ta ju oma maheduselt muusade ühtelaulmisega ning taastub ju igapäevastes argiaskeldustes kulutatud vaim kõige paremini just luulekunsti võluga.

2. Kas ootate, et selgitaksin tema kasulikkust? Selgitaksin teiste sõnu kasutades, nii nagu Horatius on ülikaunilt kirjutanud oma „Luulekunstis“:

Orpheus, preesterlik tõlk, püha taevaste tahtmise tundja,

võõrutas metslaste soo tapatöist ning roojasest toidust:

siit siis jutt, et ta teeb lõvid taltsaks ja raevused tiigrid;

käib veel jutt, et ka Amphion, kes rajas linnuse Teebas,

liigutas kaljusid kord, oma lüüraga juhtides leebeil

palveil neid, kuhu tahtis ta meel. Oli tarkuseks muiste

tõmmata piir ühis- ning eraasjades, vaimses ja maises,

peatada eksisklev kiim, teha õigused naitunu tarvis,

linnasid kerkima panna ja lõigata seadused puusse.

Sel moel endale au ning kuulsuse said ülemaised

lauljad ja laul. ${ }^{5}$

(b) Cicerogi kirjutas [sic!] Archiase kaitseks esinedes silmapaistvalt luulekunstist, et too olevat järginud luulekunstiõpinguid sellise hoolega, et ükski hüve ei ole teda kirjanduse juurest iial ära kutsunud ega ükski puhkeaeg eemale vedanud ega nauding eemale ahvatlenud ega lõpeks ükski unigi loiumaks muutnud. Ja ehkki Cicero oli ülimal määral haaratud ühiskondlikest kohustustest, ei lasknud ta kunagi meelest

\footnotetext{
4 Ingemar Smetander Västergötlandist õppis 1636-1638 ning 1641-1643 Tartus, 1644-1657 töötas Skara triviaalkooli rektorina (Tering 1984: 161, nr 187).

5 Horatius „Luulekunstist“, värsid 391-401 (RKA 1971: 350, tlk Ülo Torpats).
} 
minna hariduse poole püüdlemist ega arvanud, et keegi võiks teda seadusega takistada, et nii palju aega, kui teised veedavad oma asju ajades, pidupäevi tähistades, niipalju kui epikuurlased loovutavad ülimale hüvele ning hinge ja keha puhkusele või niipalju kui teised maha sahkerdavad rikkalikel pidusöökidel, täringu- ja pallimängudel, sama palju võib tema võtta teaduste viljelemiseks.

(Smetander 1638: B3.)

1641. aastal puudutas Rootsi päritolu Martin Faxelius ${ }^{6}$ „Kõnes vabade kunstide olemusest ja omandamisest" viimase osana vabade kunstide loetelus luulekunsti. Ka tema ei püüdnud käsitleda luuletamist teistele distsipliinidele vastanduvana, vaid võrdsena teiste kõrval. Kui Smetander mainis luulekunsti teraapilist ning ühiskonda ja indiviidi tsiviliseerivat rolli, siis Faxeliusel väärib luulekunst esiletõstmist ühiskondliku mõjukuse tõttu:

(Argument 20. Eeldus). Kõnekunsti naabriks on luulekunst. On ju kiituse ja laituse puhul suurim jõud just luuletajal, sest

(Põhjendus): See, kes annab õilsale kuningale kas maad või kulda, hõbedat, laudu, toidunõusid, maju, annab ihkavale Curiusele, Crassusele ja väikesest võimsaks saanud Fabriciusele kinke, mis on ohtlikud Midasele. Kuulsad juhid ei inka kulda, vaid kiituse kaunist austust ja au ja kuulsat nime.

See, kes annab kuningale laule, annab talle kuningate kinke elab ju Caesar pärast eluaega oma elu edasi lauludes. Laulus elab ka suur Achilles, kes praeguseks on surnud, alati on laulus elav olnud ka Alkiid.

Sa ütled ehk, et sinu laul ei ela tulevikus. Tee nii, et ta elaks, tahtagi on juba piisav.

(Faxelius 1641: C3 pöördel.)

Smetanderi käsitlus tugineb läbinisti kahe traditsioonilise antiikrooma autoriteedi, Horatiuse ja Cicero kanoonilistele tekstidele, vastavalt „Luulekunstile“ ning „Kõnele Archiase kaitseks“, Faxeliuse mõttekäik kasutab aga Itaalia renessansihumanisti, Modenast pärit Pamphilus Saxuse (Panfilo Sasso, umbes 1450-1527) epigrammi 1,2, mis ilmus humanistide luuleantoloogiates pealkirja all „Luuletuste ülistus“ („Laus Carminum“). Eeskujuidee luuletajaist kui väe- ja riigijuhtide kuulsuse tegelikest jäädvustajaist on muidugi antiikne. 
Millise antoloogia vahendusel Tartus seda epigrammi täpselt tunti, ei ole õnnestunud seni kindlaks teha. ${ }^{7}$

Teiseks oluliseks sissejuhatuseks enne iseseisvalt sõnastatud poeetikakäsitluste ilmumist oli Tartus 1641. aasta maikuus akadeemilise harjutusdisputatsiooni vormis poeetikaprofessor Laurentius Ludeniuse juhendamisel ning Västgötlandist pärit Nicolaus Ramziuse ${ }^{8}$ respondeerimisel toimunud väitlus „Quintus Horatius Flaccuse raamat „Luulekunstist““ (Ludenius, Ramzius 1641). Horatiuse 476 värsi pikkusest, assotsiatiivse ülesehitusega värsskirjast on välja valitud 160 värsirida ning grupeeritud need kuueks, proosavormis vahepealkirjadega varustatud luuletamisalaseks reegliks:

1) poeet peab olema loogiline ja kirjutama metoodiliselt,

2) poeet peab olema hea kõnemees,

3) poeet peab olema eetiline, järgides oma loomingus kohasuse printsiipi,

4) poeet peab valdama eri luuležanridele kohast väljendusviisi,

5) poeet peab tundma luule loomise põhjusi,

6) poeet peab teadma, milliseid vigu vältida.

Iga reegli juurde grupeerus veel rida alapunkte (kokku 45), enim luuležanride lähikäsitluse (15) ning luule loomispõhjuste reegli juures (14).

Sellise Horatiuse teksti selektiivse ja vahepealkirjastatud väljaandega esindas Ludeniuse ja Ramziuse käsitlus Horatiuse standardteose retoriseeriv-pedagoogilist retseptsiooniharu, mis oli alguse saanud hilisantiikse kommentaatori ja grammatiku Helenius Acro ehk PseudoAcro skolionidest. Pseudo-Acro oli 2. sajandil pKr esimesena kirjutanud Horatiuse teose ümber normatiivseks poeetika- ja retoorikakäsiraamatuks (minu rõhutus - K. V.) ning tõlgendanud Horatiuse arvukaid sententse, võrdlusi, allegooriaid ja näiteid kui kindlaid reegleid. Ühtlasi oli Pseudo-Acro seganud Horatiuse poeetikaalaste seisukohtadega ka Rooma vabariigi aegsete retoorikakäsitluste, eriti Cicero teosest „Ainestiku leidmisest“ („De inventione“) pärit ideid. Pseudo-Acro kommentaarist oli läbi keskaja retseptsioonifiltri kujunenud Euroopa renessansiaegse koolihumanismi keskne lähenemisviis Horatiuse "Luulekunstile“. Koolihumanismile iseloomulik käsitluslaad, mis vältis nii Horatiuse seisukohtade distantseeritud kristianiseerimist Wittenbergi reformaatorite kombel (seda asendab Ludeniusel ja Ramziusel mõneti poeedi eetilisuse nõue) kui ka satiirilist poleemikat Julius Caesar Scaligeri poeetika laadis, oli 17. sajandi avapoole Saksamaal ilmunud ladinakeelsetes luuleteoreetilis-

7 Nt esineb see luuletus antoloogias Mirabelli, Tortius 1600: 665.

8 Nicolaus Ramzius õppis Tartu Akadeemias 1633-1642, sai 1642. aastal Tartus magistriks, 1643 Göteborgi kooli füüsikalektoriks ning 1650 sealse gümnaasiumi professoriks, alates 1665. aastast oli samas teoloogia lektor (Tering 1984: 150-151, nr 117). 
tes tekstides väga levinud ja mõjukas, nii et sellest juhindus üldjoontes ka Martin Opitzi "Raamat saksa luulekunstist“ („Buch von der deutschen Poeterey“, Opitz 1963 [1624]). ${ }^{9}$

Ehkki Ludeniuse-Ramziuse käsitluses on Horatiuse „Luulekunstist“ kasutamist leidnud ainult kolmandik värsse, ei saa välja jäetud värsside põhjal ometi teha järeldusi poetoloogiliselt vähem huvipakkuvate küsimuste kohta Eesti- ja Liivimaa kirjanduskultuuri jaoks, sest kõik tekstikatkendid Iõppevad Tartu trükises lühendiga et cetera.

Teadaolevalt on meie ajani säilinud ainult üks eksemplar sellest Tartus avaldatud Horatiuse värssepistli töötlusest (Växjö maakonnaraamatukogus) ja selleski puuduvad otsesed käsikirjalised kasutusjäljed (Jaanson 2000: 231, nr 296). Poeetikateooria alase disputatsiooni respondeerimine ei suunanud ka väitlejast üliõpilast Nicolaus Ramziust ennast aktiivsele luuletegevusele. ${ }^{10}$ Ent just 1638. aastal peetud Ingemar Smetanderi kõne taustal kinnitab 1641. aasta disputatsioon, et Tartu Akadeemias oli Horatiuse-Cicero ideede kombinatsioon algselt poeetikaalase mõtte domineerivaks eeskujuks.

\section{Kaks poeetikaalast kõnet Tartu akadeemias}

Regiooni varaseimad terviklikud ladinakeelsed iseseisvad poeetikakäsitlused ilmusid alles pärast kõrgemate akadeemiliste õppeasutuste ja trükikodade pikemaajalist tegutsemist Tartus ja Tallinnas. Tartus muutus luulekunsti alane refleksioon intensiivseks 1640. aastail, mil järjestikku ilmus Riia päritolu üliõpilase Jakob (Jacobus) Lotichiuse „Kõne luulekunstist“ (Lotichius 1642) ning Rootsimaalt tulnud Jakob (Jacobus) Columbuse „Värsskõne luule kiituseks" (peetud detsembris 1645, trükitud: Columbus 1646). Mõlemad mehed olid ise praktiseerivad luuletajad, kes katsetasid paljudes meetrumites ja teemadel.

Riia kantori poja Jakob Lotichiuse ${ }^{11} 23$ värsstsitaadiga proosakõne on esituselt lakooniline ja stiililt neutraalne ega võta luulekunsti suhtes ülistavat, kuid mitte ka alavääristamise eest kaitsvat hoiakut, vaid sarnaneb informatiivsuselt ja argumenteerituselt pigem dotseeriva ja defineeriva loengukonspektiga. Esmakordselt Eesti- ja Liivimaal kinnitab see trükis humanistlikest poeetikaalastest kompilatsioonidest pärit kesksete poeetikaalaste tüüpideede teadvustamist regioonis. Luulekunstile ei ole vaadatud enam üksnes läbi kitsa HoratiuseCicero prisma, vaid esindatud on avar valik antiikseid ja varauusaegseid poeetikaalaseid autoriteetseid seisukohti. Kreeka autoreist on leida Platoni luuletajaid hindav mõttekäik dialoogist "Lysis“, 214b ning Nazianzose Gregoriuse „Dogmaatilistest luuletustest“ („Isast“, 1, 6-8), roomlastest Enniuse („Incerta“, frgm. 19), Horatiuse (nii „Luulekunstist“ kui ka

\footnotetext{
9 Horatiuse „Luulekunstist“ ülejäänud käsitlussuundade kohta vt sissejuhatavalt Richter 2011: 933-956.

10 Ramzius avaldas kümne õpiaasta jooksul Tartus kõigest kolm juhuluuletust (Orion, Viiding 2002).
}

11 Jakob Lotichius (1617-?) õppis enne Tartusse tulekut Danzigi gümnaasiumis, 1637-1642 Tartu akadeemias, vt Tering 1984: 172, nr 249; Viiding jt 2007: 58-65, 150-153, 202-205, 326, 365-366. 
„Kirjad“, 2, 1), Ovidiuse („Metamorfoosid“, „Fasti“, „Armukunst“) ja Claudianuse („Ülistus FI. Mallius Theodori konsulaadi puhul“) seisukohad luule jumalikust päritolust ning luuletaja jumalikust loomusest, luule kõrgest vanusest, jumaliku inspiratsiooni versus harjutamise ja meisterlikkuse osast luule loomisel, luule- ja kõnekunsti ühisosast ja erinevustest, luule eetilisest rollist moraalieksimuste parandajana, intellektuaalsest rollist inimlike teadmiste vahendajana, emotsionaalsest rollist rõõmu valmistajana ning religioossest rollist jumala ülistamisvahendina. Saksa uusladina poeetidest näitlikustas Georg Fabriciuse luuletus luulet kui kommete korrigeerimise ja emotsioonide taltsutamise vahendit (luuletus „Lapselaps Martin Pisole luuletajate väljapaistvusest roomlaste juures“ („Ad Martinum Pisonem avunculum, de excellentia poetarum apud Latinos“), v 5-16, 20-21, 42-47).

Erinevalt regiooni varasematest fragmentaarsetest poeetikakäsitlustest on Lotichiusest alates pööratud tähelepanu luulekunsti kristlikule olemusele. Poeetika on ühes luulega Jumala ainukordne kingitus (Lotichius 1642: C2), ka toetumisvõimalust varasematele autoriteetidele peetakse kristliku jumala kingituseks: „Ja me avaldame tänu ülivõimsale Jumalale, et meil on meie eluajal olemas muistsed poeedid, kes on ülimad meistrid luulekunsti alal ja kes on meile eeskujuks nii reeglite kui ka näidetega“" (samas, B).

Samuti on jumala and see, et majesteetlikud valitsejad on toetanud luuletajaid ülisuurte heategudega. Viidatud on varauusaegsele kroonitud poeedi institutsioonile ja näitlikustatud seda nelja poeedi, Conrad Celtise, Heinrich Eccardi, Elias Corvinuse ja Johannes Lauterbachi kroonimisega (samas, A3 pöördel).

Siiski on Lotichius kristlikule humanismile tüüpiliselt seganud paganlikku antiiki ja kristlikke näiteid luuletamisest tasakaalustatult: Piibli värssosi, Pauluse luuletsitaate ega kirikuisade luuletusi pole tõstetud väärtuslikumaks paganlike poeetide teostest. Mesilaste kombel tuleb poeedil noppida kõikjalt ja kõigist õitest:

\footnotetext{
Lausuksin nii, nagu asi on: meil tuleb tundma õppida luuletajate parimaid väljendeid ning lugeda seda, mida teised on kasutoovalt reeglistanud. Selleks et meid nähtaks püüdlemas eruditsiooni saavutamise poole, ei jäta me miskit uurimata, vaid kogume kõikjalt kasutoovat - justkui mesilased, kes istuvad kõigil õitel, ent nopivad üksnes kasulikku. (Samas, C2.)
}

Lotichiuse kõne peamine eripära regiooni ülejäänud poeetikatega võrreldes on kõne keskkoha pikk ekskurss värsistamise kui luuletuse loomise põhielemendi kohta. Kõnekunstiga ühised pädevused, s.t kohase ainese leidmise, sobiva struktureerimise ja kaunistamise oskus on Lotichiuse meelest luuletajale vajalikud, kuid need on luuletuse kvaliteedi hindamisel teisejärgulised:

Ehkki hea kõnemees võib olla seotud proosarütmiga, on poeet luulerütmiga seotud siiski nii tihedalt, et eksides silbiga ei leidu sellist, kes ütleks tema kohta, et tal on kohane sissejuhatus, selge jutustamine, 
teravmeelne väitestik, tugev seotus, erakordne kaunistatus, kohane õpetatus, mahe meelelahutus ja meeldiv emotsionaalsus. (Samas, A4 pöördel.)

Primaarne on värsistamisoskus ka luule eesmärgi saavutamisel, s.t just tänu värsistatusele „tekitab luule kuulajate südames meeldivust ja rõõmu“ (samas, B3).

Seetõttu on luuletaja peamisteks abivahenditeks riim, meetrum, prosoodia, tsesuur jne, mida kirjeldades toetub Lotichius Julius Caesar Scaligeri kanoonilisele humanistlikule poeetikale „Seitse raamatut poeetikast“ („Poetices libri septem“, Scaliger 1561) teise raamatu peatükkidele 2-23. See osa Lotichiuse kõnest meenutab seetõttu pigem praktilisi luuletamiskäsiraamatuid kui teoreetilis-kriitilisi seisukohavõtte või luuletamise ajalugusid:

Nõnda kasutab luuletaja mõnikord sobivat riimi.

Kaunis riim on see, mis tänu sarnastele silpidele värsilõppudes mõjub kuulajale vägagi.

Meesriim toob meeldivust, naisriim on värskendav, daktülriim paneb rõõmustama, neljasilbiriim toibutab, enamate silpide riimumine innustab. Versi cancellati panevad kaasa liikuma, versi alternati ergutavad, segariimid köidavad.

Luuletaja kasutab oma rütmistatud kõnes meetrumit.

Sest tal tuleb tähele panna, milline on silpide kestus ja vältus. Arvestades pikki, lühikesi ja muutuva vältusega silpe, kohandavad nad ju nagu üliandekad lauljadki oma sõnad muusika pikkusele.

Ta paneb tähele, kuidas värsijala määratlevad kindla pikkusega silbid, kuidas moodustatakse spondeus, pürrikus, jamb, trohheus, kuidas daktül, anapest, moloss, tribrahh, bakkius, antibakkius, amfimaker, amfibrahh, kuidas kaksikspondeus, korijamb, antispast, kaksikjamb, esimene, teine, kolmas ja neljas paeon, esimene, teine, kolmas epitriit ja teised värsijalad. ${ }^{12}$

Luuletaja peab silmas värsijalgade sobivat ühendamist.

Sest kui juhtub, et ta mõnes positsioonis mõnikord kõigest ühe, teinekord aga licentia poetica'le toetudes rohkem värsijalgu ära jätab, siis jälgib ta hoolikalt, et ta kuidagigi kompositsioonis ei eksiks.

Ta mõtiskleb värsirea lõpetamise üle: akatalektilised värsid koosnevad tal tervetest värsijalgadest, milles ei ole puudu ega üle ühtki silpi. Kui aga on tegemist katalektiliste värssidega, siis puudub neil viimasest värsijalast silp. Ja kui on tegemist hüperkatalektiliste värssidega, siis on neil lõpus värsijalg, mis ulatub üle jala piiri. ${ }^{13}$

Samuti jälgib luuletaja hoolikalt meetrumi seoseid.

Ta loeb värsse skandeerides ja arvutab kokku värsijalad.

Tal on värsiskeemid, mis muudavad tavakõne laadi sageli värsi tõttu teistsuguseks.

12 Vrd Scaliger 1561, rmt 2, ptk 4.

13 Vrd samas. 
Tal on tsesuur, mis annab luuletusele harukordse võlu. ${ }^{14}$

Värsimõõdu liikidest ma pikemalt ei pajataks.

Sest teate ju, et värsimõõt saab nime peamise värsijala järgi, ja nii on olemas jambiline, trohheiline, daktüliline, anapestiline, korijambiline, antispastiline, jooniline, paiooniline värsimõõt. ${ }^{15}$

Ja nii nagu on palju üksikjalgade liike, nii on mõistagi olemas ka monomeetrilised, dimeetrilised, trimeetrilised, tetrameetrilised, pentameetrilised ja heksameetrilised värsid. ${ }^{16}$

Leidub ka liitvärsimõõte, mistõttu kutsutakse värsse akatalektilisteks, prokatalektilisteks, epikatalektilisteks ja dikatalektilisteks. ${ }^{17}$

(Samas, B3 pöördel - B4.)

IImumisajalt teine Tartu poeetika, Jakob Columbuse ${ }^{18} 411$ värsi pikkune „Värsskõne luule kiituseks" on samuti ajastutüüpiline, kuid ilma otseste didaktiliste eesmärkideta ülistus luulele ja eriti sellest sündivale hüvele (värss 38). Kasutoovana käsitleb autor üksnes eepilist ja didaktilist, mitte lüürilist luulet, s.t seda osa värsstekstidest, mis toob inimesteni uusi teadmisi. ${ }^{19}$ Luule on tänu värsivormi mnemoonilistele omadustele ajaloo-, religiooni-, õigusteaduse-, eetika-, meditsiini-, geograafia- ja astronoomiaalaste teadmiste parim vahendaja. Seda kinnitab autori jaoks ka antiikaja luule ajalugu: algsest tsiviliseerimata maailmast sai tsiviliseeritum just tänu Orpheuse loomingule (värsid 83-98).

Columbuse värsskõne esimese osa (värsid 1-226) moodustab luuletamise ja poeetika valikuline ajalugu. Eeskujuautoritena kuuluvad sellesse tema arvates Cato distihhonid, pütagoorlaste luuletused, Ovidiuse „Metamorfoosid“, Lucretiuse „Asjade loomusest" ning Vergiliuse eeposed "Georgica“ ja "Aeneis“. Poeetika alal on nimetamisväärseteks autoriteetideks Aristoteles ja Platon, tsitaatide põhjal ka Horatiuse teos „Luulekunstist“. Ühtki kritiseerimis- ja vältimisväärset poeeti Columbus ei nimeta.

14 Vrd samas, ptk 2.

15 Vrd samas, ptk 7-23.

16 Vrd samas, ptk 6.

\section{Vrd samas.}

18 Jakob Columbus (surn 1655) immatrikuleerus Tartu akadeemiasse 1643. aastal, oli kogu õppeaja vältel Riia kuberneri stipendiaat, aktiivne kõnepidaja ja disputeerija, kirjutas arvukalt juhuluulet (Orion, Viiding 2002). Lahkus Tartust pärast 1646. aasta juunikuud, töötas 1650-53 Skara kooli konrektorina, 1654-55 sealse gümnaasiumi ajaloolektorina (Tering 1984: 214, nr 515).

19 IImselt regiooni oludest tingituna ei käsitletud ei Tartu ega Tallinna poeetikates ühtki draamažanride poeetikaga seotud probleemi, ehkki antiiksetes eeskujukäsitlustes Aristoteleselt ja Horatiuselt on just draama kõige ulatuslikumalt käsitletud osa. 
Columbuse poeetika teine pool (värsid 227-411) tematiseerib luulekunsti looja, luuletajaga seotud probleemistiku. Autor esindab seisukohta, et isegi kui luuleteoste teemaks on inimmõistusele haaratavad teadmised, jääb luuletamisoskuse omandamiseks siiski mõistuse jõust väheks ning vaja on ka jumalikku sädet (värsid 227-228). Poeetikakäsiraamatud võivad õpetada küll valima sõnu, meetrumit ja seada luuleteosele õigeid eesmärke, kuid nad ei saa tagada luuletaja jumalikku sädet ega ennustajavõimeid (ladina sõna vates tähistab nii luuletajat kui ka ennustajat), milleni antiikautoritest parimad ju jõudsid. Ühe näitena toob Columbus Seneca tragöödia „Medea“ värsid 374-378, milles Seneca ennustavat uue mandri avastamist kauges ookeanis, Ultima Thulest kaugemal, ja mida peetakse Ameerika avastamise ettekuulutajaks. Luuletamiseks vajalike tingimuste kombinatsioon, s.o mõistuse ja jumaliku sädeme olemasolu, tingib Columbuse arvates selle, et ühiskonnas on häid luuletajaid palju vähem kui häid poliitikuid.

Olulise tähendusega on Columbuse poeetika puhul meetrumi valik. Ladinakeelsete poeetikate kanoonilise teose, Horatiuse „Luulekunstist" heksameetrite asemel valis ta kirjutamiseks eleegilised distihhonid. Nõnda paigutas ta end pigem sellesse õpetusluule traditsiooni, mille antiikseks peaesindajaks Rooma poeetide seas oli Ovidius.

\section{Johannes Hörnicki luulekunstikäsitlus}

Kui Tartus ilmunud poeetikate autoreiks olid eranditult üliõpilased, nii et neid tekste võib käsitleda õppeprotsessi osana, siis Tallinna gümnaasiumis käsitles luulekunsti 23-aastase poeetika- ja kõnekunstiõppejõu kogemusega Johannes Hörnick oma inauguratsiooniloengul 1671 laiema haritlas- ja ametnikkonna ees. Praegu teadaolevail andmeil jäi Hörnicki kõne (Horniceus 1671) ühtlasi viimaseks ladinakeelseks luulekunsti alaseks käsitluseks Eesti- ja Liivimaal. $^{20}$

Johannes Hörnick (latiniseeritud humanistinimega Horniceus) Plauenist Vogtlandis (1621-1686) oli töötanud alates 1648. aastast Riia Toomkoolis, algul õpetajana (collega), alates 1655. aastast konrektori ja 1658. aastast rektorina. 1671. aastal kolis ta Tallinnasse, asus siin tööle gümnaasiumi luulekunsti professorina ning 1678-1683 ka kõnekunsti ja ajaloo professorina. Elu Iõpuaastad veetis ta Riias. Tema poeg David Hörnick (1665-1697) oli hiljem Riias luulekunsti professoriks (von Recke jt 1828: 319-321). Johannes Hörnicki õpetatus oli tuntud veel 19. sajandilgi (Buchholtz 1890: 70).

Hörnicki poeetika ei ole õpikulaadselt struktureeritud ega õppematerjalina kasutatav, vaid esseelaadne teemakäsitlus. Kõne sissejuhatava osa, s.o teemavaliku põhjenduse järel esitab Hörnick provotseeriva teesi luulekunstist kui kõlvatust naisest, kellel ei tohiks olla normaalses ühiskonnas kohta, vastandades sellele idee, et luulekunst peab tooma kasu ja 
lahutama meelt. Järgnevas asub ta luulekunsti kaitsma, jälgides esmalt luulekunsti kasulikkust selle algupärast lähtudes, seejärel luulekunsti võimet inimesi vooruse, kõneosavuse ning haritud ja rikkaliku keeletarvituse poole juhtida. Luulekunsti meeldivuse tõestusena toob ta esile asjaolu, kuivõrd meeldiv on viibida poeetide seltskonnas ja kuivõrd sügava mõjuga on kvaliteetne luule. Käsitlus Iõpeb tänuavaldustega Rootsi valitseja ja ametnike aadressil ning tõotusega pühenduda professoriametis täiesti luulekunsti väärikuse tagamisele.

Regiooni poeetikate seas on Hörnicki oma ainulaadne põhjusel, et ta rõhutab luuletamise tähtsust keele arendamisel ja rikastamisel. Vahetule seisukohavõtule lisaks kinnitab Hörnick seda ka oma kõnesse arvukate haruldaste ladina sõnade lisamisega. Paljud kasutatud sõnadest on seejuures antiigijärgset päritolu.

Hörnicki poeetikaalasele kõnele on lisatud kolm parateksti: pühendus tollasele Eestimaa kubernerile Hornile ning õnnitlusluuletused Hörnickile Oleviste pastorilt Joachim Salemannilt ning Niguliste pastorilt Gottfried Stecherilt. Salemann pühendub Horni metseenirollile Hörnincki suhtes, õpetamistöö tänamatusele ning palub lõpuks Jumala õnnistust vastsele professorile. ${ }^{21}$ Stecher vaatab oma samuti eleegilistest distihhonides kirjutatud luuletusega tagasi Hornincki varasematele õpetamisaastatele Riias ning õnnitleb Tallinna gümnaasiumi sellise professori saabumise puhul. ${ }^{22}$ Lapidaarstiilis ja eri mõõtu suurtähtkirjas kujundatud pühendus Benedictus Hornile ülistab Tallinna asekuberneri ajastutüüpiliste ülivõrdes epiteetide ja võrdlustega (Horniceus 1671: A3 pöördel-A4).

\section{Ki r jandus}

Buch holtz, Arend 1890. Geschichte der Buchdruckerkunst in Riga 1588-1888. Festschrift der Buchdrucker Rigas zur Erinnerung an die vor 300 Jahren erfolgte Einführung der Buchdruckerkunst in Riga. Riga: Häcker.

Columbus, Jacobus 1646. In laudem poeseos oratio metrica, quam [---] in Regia Academia Gustaviana Adolphina, quae Dorpati Livonorum est ad Embeccam, in Auditorio Magno, Die 10. Decemb. Anno 1645 publice pro concione enarrabat Jacobus Petri Columbus, Svecus. Dorpati: J. Vogelius.

21 (1) Oo Hörnick, Sulle oli metseeniks kuulus kangelane Horn, Eestimaa satraap, suursugune ehe. Õnnitlen ameti puhul, mida selle patrooni juures täidad, ning õnnitlen, et just tema on su metseeniks. (5) Olgu Horn kaua võimas ning soosigu meie lütseumi, milles viibigu ja edenegu kaua head muusad! Ka sina, Hörnick, õilmitse, ning kaunista ametit, mida täidad, pakkudes noorsoole oma tuhandeid hüvesid. (9) Ehkki tänumeel on maailmas haruharv, on taevas siiski rikkalik vaevatasu. Sina, Jumal, ole alustatule soosiv, anna kõrgelt õiget vaimu, kelle juhtimisel õnnestub kõik hästi! (Horniceus 1671: A4 pöördel)

22 (1) See, kes senini vormis Riias hoolikalt ja oskuslikult aoonialasi, tuues muusadele tuhandeid hüvesid, inkab nüüd saatusest kantuna meie muusasid aidata ja taas kindlustada kõikuvat kooli. (5) Seetõttu õnnitlen ma Tallinnat, muusasid ja meie kooli, sest sellise külvajaga hakkab see andma kauneid võrseid. (7) Elagu see muusade ehe, kandku oma ametikohust, nii et alati oleks õitsengus kirikud, koolid, kohus. (Samas, A4 pöördel.) 
Faxelius, Martin 1641. Oratio de artium liberalium natura et studio: Quam, [---], In Regia Academia Gustaviana, quae Dorpati est ad Embeccam, Amplissimo in consessu, die 27. Januarij, Anno 1641. publice memoriterque in Auditorio Majori pro concione enarrabat M. Martinus Nicolai Faxelius, Nerichia Svecus. Dorpati: Typis Academicis.

Horniceus, Johannes 1671. Poeseos laus, oratione inaugurali, in Gymnasio Revaliensi, delibata, Cal. Maji, A. MDCLXXI. Revaliae: A. Simon.

J a a n s on, Ene-Lille 2000. Tartu Ülikooli trükikoda 1632-1710. Ajalugu ja trükiste bibliograafia. Tartu: Tartu Ülikooli Raamatukogu.

Kaju, Katre (koost) 2014. Tallinna linna- ja gümnaasiumitrükikoda (1634-1828). Näituse kataloog. Tallinn: Tallinna Ülikooli Akadeemiline Raamatukogu, Tallinna Linnaarhiiv.

Lindemann, Andreas 2008. Gott und die Götter - Paulus, Lukian von Samosata und „Der Brief an Diognet“. - Paulus und die antike Welt: Beiträge zur zeit- und religionsgeschichtlichen Erforschung des paulinischen Christenthums. Eds. D. C. Bienert, J. Jeska, Th. Witulski. Göttingen: Vandenhoeck \& Ruprecht, S. 33-55.

Lotichius, Jacob 1642. Oratio de poetica: quam [---] in Regia Academia Gustaviana, quae Dorpati Livonorum est ad Embeccam, die 4. Junij. Anno 1642 [---] publice in Auditorio Magno enarrabat Jacobus Lotichius Rigensis Livonus. Dorpati Livonorum: Typis academicis.

Ludenius, Laurentius, Nicolaus Ramzius 1641. Q. Horatii Flacci De Arte poetica liber; Qui, [---] In Regia Academia Gustaviana, quae Dorpati est ad Embccam, horis a 7. mat[utinis] 12. die Maji Anno 1641. publice in Auditorio Majori, placidae Disputationis Exeritio committebatur, praeside Laurentio Ludenio, Holsat. Ph. et J. U. D. Poet. C. Professore Juris, Oratoriae et Poeseos, respondente Nicolao Ramzio, WestGotho. Dorpati Livonorum: Typis academicis.

Mirabelli, Domenico Nani, Francius Tortius 1600. Polyanthea: hoc est opus suauissimis floribus celebriorum sententiarum tam Graecarum quam Latinarum exornatum [---]. Lugduni: sumptibus Haeredum Eustachii Vignon.

Opitz, Martin 1963 [1624]. Buch von der deutschen Poeterey. Ed. R. Alewyn. Nach der Edition von Wilhelm Braune neu herausgegeben. (Neudrucke Deutscher Literaturwerke Neue Folge, 8). Tübingen: Max Niemeyer.

von Recke, Johann Friedrich, Karl Eduard Napiersky 1828. Allgemeines Schriftsteller- und Gelehrten-Lexikon der Provinzen Liv-, Esth- und Kurland, 2. Mitau: Steffenhagen und Sohn.

Richter, Sandra 2011. Außer Konkurrenz? Die Ars poetica des Horaz in Kommentar und Poetik des 16. und 17. Jahrhunderts. - Welche Antike? Konkurrierende Rezeptionen des Altertums im Barock. Ed. U. Heinen. Bd. 2. (Wolfenbütteler Arbeiten zur Barockforschung, Bd 47). Wiesbaden: Harrassowitz, S. 933-956.

RKA 1971 = Rooma kirjanduse antoloogia. Toim. A. Kaalep, Ü. Torpats. Tallinn: Eesti Raamat 1971.

Scaliger, Julius Caesar 1561. Poetices libri septem. Faksimile-Neudruck der Ausgabe von Lyon 1561 mit einer Einleitung von August Buck. Stuttgart-Bad Cannstadt: Friedrich-Fromann.

S metander, In gemar 1638. Oratio de artium liberalium jvcvnditate et utilitate: Quam, [---], In Regia Academia Gustaviana, quae Dorpati est ad Embeccam, 13. die Aprilis, Anno 1638. publice pro concione enarrabat, Ingemarus Petri Smetander, WestroGothus. Dorpati: Typis academicis.

Tering, Arvo (koost) 1984. Album Academicum der Universität Dorpat (Tartu) 1632-1710. (Publicationes Bibliothecae Universitatis Litterarum Tartuensis, 5). Tallinn: Valgus. 
Viiding, Kristi, Jana Orion, Janika Päll (koost) 2007. O Dorpat, urbs addictissima musis. Valik 17. sajandi Tartu juhuluulet. Tallinn: EKSS.

Vossius, Gerhard Johannes [1680]. Elementa rhetorica, prout aucta prodierunt opera viri cl. M. Joh. Sebastiani Mitternachts, autoritate publica in usum gymnasii Regio-Revaliensis edita. Revaliae: C. Brendeken.

\section{Ve e b i a I I i k a d}

Orion, Jana, Kristi Viiding 2002. Academia Gustaviana (1632-1656) ladinakeelse juhuluule tekstikorpus. Korpus der akademischen Gelegenheitsdichtung an der Academia Gustaviana (1632-1656). Elektrooniline tekstikriitiline tekstikorpus, varustatud indeksite ja eessõnaga. - http:// www.ut.ee/klassik/neolatina (8.11.2015)

Kristi Viiding - eesti klassikaline filoloog ja tõlkija (PhD 2002), Tartu Ülikooli klassikalise filoloogia professor. Peamine uurimisvaldkond: 16.-17. sajandil Läänemere ümbruses, eriti Eesti- ja Liivimaal loodud ladinakeelne kirjandus.

E-post: kristi.viiding[at]ut.ee 


\section{Luulekunsti \\ ülistus, \\ esitatud}

Tallinna gümnaasiumis

inauguratsioonikõnes

maikuu kalendidel ${ }^{23}$ 1671. aastal.

Tallinnas,

trükkis Adolph Simon, gümnaasiumi trükkal.

Oo kuningriigi silmapaistvaim ja väljapaistvaim nõunikuisand, kuberner ja kuninglik peaasehaldur, armulisim isand, üliheasoovlik kaitsja! ${ }^{24}$ Oo suursugused, kõrgeaulised, kõrgestisündinud, ülimalt austatud, mõjukaimad, nõukaimad, kogenuimad, arukaimad, kuulsaimad, harituimad, targimad, tunnustatuimad mehed! Üliimetletud, üliaulikud, otsusekindlaimad metseenid, patroonid, soosijad! Ja sinagi, vabade kunstide meeldivusest kiiduväärselt toitunud noorsugu! Iga kord kui pöörame uudishimuliku pilgu veidikegi selja taha, paneme tähele imeväärseid ja jahmatavaid muutusi kõigis asjades. Sest on ju nii, et ilma minu manitsusetagi torkavad teile tähelepanelikult vaadates kõikjalt silma Babüloonia ehitiste rusud, Pärsia luksuste kõduhunnikud, segipaisatud Makedoonia hiilgus ja Rooma impeeriumistki üksnes savikillud. Kõigele siin päikese all kehtib ühtne seadus: kindlad asjad rabenevad, ülimad langevad põrmu, kuulsad vajuvad hämarusse, teisalt aga saavad nõrgad tugevust juurde, mahasurutud ajavad end sirgu, hämarad tõstetakse kuulsuse ja au säravaimasse valgusesse. Kes nägi kahesaja aasta eest undki sellest, et leidub veel üks manner? Ent see avastati, allutati ja sai kuulsaks. ${ }^{25}$ Aga miks loetlen vanu või väga kaugeid asju? Piiritlegem siin meie Põhjalas, söakas Rootsi kuningriigis, oma käsitluse sihina Liivimaa, koguni üksnes Eestimaa. Milline oli mõne sajandi eest siinne olukord? Kes olid asukaiks? Pärismaalased, kes polnud kiiduväärt üheltki oma oskuselt ega ka kirjanike meenutustes. Sest nii nagu Tacitusel

\section{S.t 1. mail.}

24 Vabahärra Benedictus/Bengt Horn (1623-1678) - Rootsi poliitik ja väejuht, 1656-1674 Tallinna ja Eestimaa kuberner, alates 1660. aastast Rootsi riiginõunik, 1672 Eestimaa kindralkuberner; Rootsi delegatsiooni juht Kärde rahu sõlmimisel. Oli õppinud 1634-1637 Uppsala ülikoolis, immatrikuleerunud 18.10.1638 Tartu ülikooli, kus trükitud jälgi tema õppetegevusest siiski peale ühe pühenduse ei leidu. Hörnick lähtub Horni poole pöördumisel kuninglikus ametissemääramise aktis leiduvast ametinimetusest. Eraldi Tallinna asehalduskonda, nii nagu see oli veel 17. sajandi esimesel veerandil, sajandi keskel ega lõpuosas enam ei olnud. Kuberneri järel tegutses alati tegelik asehaldur, keda nimetati Eestimaa asehalduriks. (Tänan Enn Küngi ametinimetuste täpsustamise eest.) 
ja teistelgi mainitud aestide osas on juba iseenesestki küsitavust ja ebakindlust, ${ }^{26}$ nii ei saaks nad kuidagi olla meie Eestimaaga seotud. Ent kui vaatame [Eestimaa] tänast palet, siis kuivõrd meeldiv, kuivõrd imeteldav on siin, oo hea Jumal, kõigis asjades toimunud muutus? Ülim väärikus on neil vapraimatel sõdalastel, kes siit on viimaseil sajandeil võrsunud justkui Epeiose hobusest, ${ }^{27}$ ülim väärikus on neil, keda kogu järelpõlv imetledes jäljendab ja ülistab. Ent hoolimata innuka südame soovist loobun ma sel korral ülistamisest, mida kõik oleme neile [sõjameestele] võlgu - on ju muud asjad lähemad. Muistsete ajaloolaste hulk on arvanud ja mõni filosoofidest on söandanud isegi mine-tea-mis põhjustel veenda, et põhjarahvad on laisad ja nii loomuse kui ka kliima tõttu sobimatud teaduste mõistmiseks. ${ }^{28}$ Ent poeetide kohta räägiti, et nende muusad ei külasta neid ühelgi muul mäel peale Helikoni, Pindose ja Parnassose või mõne teise Kreekamaa mäe. Mida peaksime arvama nende viletsate varjude ${ }^{29}$ hinnanguist, kui need tulevad Elysiumi väljadelt, mille nad ise välja mõtlesid, kui see tuleb Jupiteri käsul allilmast, tolle kuulsa Mercuriuse saua abil? Kahtlemata kurdavad nad kahjatsedes taga seda, et Kreeka on lahkunud Kreekast, koguni Latiumist, hüljates Saturnuse riigi ${ }^{30}$, ja asunud enamjaolt sellele muiste põlastatud ja barbaarsele Saksamaale, koguni laisa Suure Vankri alla. ${ }^{31}$ Ent heites kõrvale luulesaua ja tunnistades avameelselt ja hardalt asjade seisu, siis oleme surematut tänu võlgu igavesele Jumalale, et ta on heldeimalt süüdanud siinses piirkonnas lisaks lunastava sõna valgusele ka vabade kunstide tõrviku. Sel moel oled õnnistatud ka sina, kuulus Tallinn, kelle jaoks avas suursuguseim aadelkond koos sinu kõrgeaulise raega kunagi selle kuulsa gümnaasiumi, õppivale noorsoole alghariduse andmiseks, tublimatele lausa viievõistluseks, ${ }^{32}$ ent nüüd soosib seda pidevalt Rootsi hiilgavaimate kuningate kuulsusrikkaim armulisus ja lihvib üliõnnestunult sinu noorsugu selles koolis

26 Tacitus „Germaanlaste päritolust ja paiknemisest“, 45. peatükk, kirjutatud 98 pKr. Hörnick on seega üks esimestest, kes aestide identifitseerimist eestlastena käsitleb ja tänapäevasel kombel välistab.

27 Epeios - Panopeiose poeg, Trooja hobuse ehitaja (Vergilius „Aeneis“, 2, 264).

28 Viide antiiksele teooriale (Hippokrates, Aristoteles, Poseidonius, Tacitus jt) kliima ja keskkonna mõjust rahva iseloomule ning õppimisvõimele oli varauusaja kirjanduses populaarne argument eri kliimavöötmete elanike kohta järelduste tegemisel.

29 S.o muusade.

30 Saturnus - muistne itali viljakusjumal.

31 Tsitaat Martialiselt („Epigrammid“ 8, 21, 3-4): pigra Bootae / plaustra („Boiotese laisad vankrid“). Bootes tähtkuju põhjapoolkera taevas, siin: Põhjala.

32 Pentathlon (kr k) - viievõistlus, koosnes esialgu kettaheitest, jooksust, kaugushüppest, maadlusest ja odaviskest. Sõna ainukasutus ladina keeles (pentathlum) on 2. sajandil pKr: Paulus Diaconus „Väljavõte Festuse „Sõnade tähendusest““, 211, 4. 
barbaarse tahumatuse eksimustest ${ }^{33}$ tänu kiiduväärseimatele professoritele, meestele, kes on ülikuulsad igal teadusalal (ilma igasuguse meelitamiskahtluseta!). Kuna olete nüüd mindki vääriliseks pidanud nende hulka liita, oo silmapaistvaim ja väljapaistvaim kuberneriisand, armulisim isand ja kaitsja ning teiegi, kõrgeaulised ja mõjukaimad mehed, auväärseimad patroonid ja metseenid, siis väljendan ma meeleldi seda lojaalsust ja tänulikkust, mida võlgnen. Ent jäägu need teie loal esialgu varju vaikivasse südamesse. Piisaku esialgu selle paiga vanast tavast - lubatagu mul lausuda introdutseerimisel mõned sõnad. Teematki ei tule kaugelt otsida, kui antakse üle luulekunsti õpetamise valdkond - kohane on pidada lühike kõne poeetikast. Palun ülialandlikult, vankumatult, et toetaksite armuliku, heasoovliku, soosiva tähelepanelikkusega seda söakat väljakutset, mille te ise olete võimaldanud.

Niisiis toon lubadust järgides teie silmapaistvaima ja mõjukaima pilgu ette Luule - kauneima, elegantseima nümfi. Oh et see lubaduse paikapidav põhjendus läheks soodsal endel! Sest vaevalt on ta puudutanud üht või teist teatrilava, kui ennäe, tabatuna pahasoovlike ründavast laimust, kattub ta häbelik palg punaga ja kui me teda kinni ei hoia, ähvardab ta vihastades lahkuda. Nimelt paiskub talle vastu rumalate vihkajate väljakannatamatu kisa: tema nägu, hoiak, kõnnak, riietus kandvat lõbunaise kergemeelsuse märke, ammuilma kupeldamises kahtlustatuna seadvat ta silmuseid noorsoo lihtsameelsusele, ta katvat omi paiseid petliku mingiga, liiderlikuna kutsuvat ta pahesid vooruse nimega, kõige suuremaid kurikaelu kuulutavat ta jumalikeks, paiskavat jumalaid inimrämpsu hulka ega jätvat taevast, maad ja allilma segades ja rüvetades kuskile midagi rikkumatut. Teenitult olevat Platon selle jumalavallatu naise eksimusi märgates ta nii paljude pahede pärast välja heitnud oma riigist, mille ta oli vorminud eeskujulikemaks; Pythagorase olevat ta aga täiesti teadlikult tagasi toonud. Homerose hinge, kes köitis väljamõeldiste ülemeelikus häbematuses jumalad pahede köidikuisse, olevat ta maokeerdudesse mässituna allilmas puu otsa üles poonud. ${ }^{34}$ Need on jultunud, ülimalt kahjutoovad eelotsused, mida meie Luulega seostatakse. Ent alandlikuna põgeneb ta teie kohtu ette, õiglaseimad kohtunikud. Ärge lükake lojaalset klienti põlgusega tagasi! Me võiksime kergesti tagasi tõrjuda selle sõimu, mida süütu kohta levitatakse. Ükski kunst ei saa oma eesmärki kõrvale heita. Nii ka luulekunst, mis pole kunstide seas just mitte viimasel kohal. Tema eesmärgiks pole mitte üksnes meelt lahutada, vaid ka kasu tuua, nagu teiste seas on kinnitanud Venuusia meeldivaim kasvandik. ${ }^{35}$ Kordan: kasu tuua, mis ei saa mingil moel sündida ilma tõe ja au abita. Kui meie Luulekunst on seega kasulike, tõeste ja auväärsete asjade austaja, siis miks saadame ta vaesekese hädaohtu? Või miks mõistame ta jooksujalu ja üle kuulamata süüdi? Halastust on väärt see, kes nii pikas

33 Strebligo, õieti stribligo (kreeka laen) - moraalne või keeleline eksimus, solötsism.

34 Luule rollile riigis on pühendatud Platoni „Riigist“ 10. raamat. Pythagorase ja Homerose võrdlust vt Platon „Riigist“, 10, 599a-600b.

35 Quintus Horatius Flaccus pärines Venuusiast, luuletamise eesmärkide kohta vt „Luulekunstist“ v. 333 : "Lauliku sooviks on tulus olla või pakkuda rõõmu“ (RKA 1971: 349, tlk Ülo Torpats). 
ajavoos on täiesti vastu enese tahet, täiesti teenimatult välja kannatanud oma riiuhimuliste kosilaste Iõputu ülekohtu. Mida arvate? Kui vägivaldne prassija ründab õilsat neiut, kes läheb Iõbu pärast jalutama, rebib talt ära loori, rebestab selle, rüvetab (olgu lubatud kasutada seda sõna! $\left.{ }^{36}\right)$ kogu tema riietuse, siis kes on häbitu? Kes on talunud vägivalda? Või kes on seda rakendanud? Seetõttu palun ma teid, kõikide seisuste auväärseimad kuulajad, juba ette, vaadata seda asja ka teiselt poolt. Sest mis on nii ülipüha, mida nurjatu pahatahtlikkus ei saaks anastada oma kõlvatute kätega? Mis on nii kaunis, mida mõni peapööritust tekitav ${ }^{37}$ Morpheus $^{38}$ ei suudaks moonutada? Kas ei pöörata noorukeste jüngrite kasulikemaidki oskusi kas siis kogenematusest või kavalusega hukule? Kui tahaksin siinkohal neid asju pikemalt käsitleda, ei oleks mu kõnel otsa ega äärt. Toit, riided, relvad on kõik eluks vajalikud vahendid ja kaunistused, kui need on antud meie alalhoidmiseks, nagu määratud. Ent kuritarvitajate käes muutuvad nad kahjutoovaks. Eraldatagu meie kunstist (kuidas peaksingi ütlema?) kahepalgeliste, paganlike, hullunud, nurjatute järgijate hullumeelsed moonutused, ja tema iseenesest on igati kiitmist ja ülistamist väärt. Olgu pealegi Platonil riik, mille ta ainult enda jaoks välja mõtles; olgu poeet selles parem kui Homeros, kui too kujutas Achilleust vapraima võitlejana, Nestorit kõneosavaima kõnemehena, Odüsseust kogenuima riigimehena - sellistena, nagu nad tegelikult on, mitte sellistena, nagu neid Platon ülespuhutud ettekujutuses aktsepteeriks. Ent Samose filosoofi jutt (seoses rumala hingederännuga) ${ }^{39}$ on kohatu ja lükatagu niivõrd kaaluka publiku poolt tagasi; selle kohta on sünnis poeedi esitatud moraal:

Peaksite naeru te siis, kui vaatama pääsete, sõbrad. ${ }^{40}$

Ent mina jätan kõrvale kogu pilkavate vaenlaste haisu ja seisan oma asja eest tõsiselt ja kohasemalt: kuulutan veendunult, et luulel on ülimeeldiv kasu ja - nagu eespool meenutatud - ülikasulik meeldivus. Ma arvan, et ei siinses silmapaistvaimas ja mõjukaimas kuulajaskonnas ega ka mujal pole kedagi (kuniks meeled on veel alles), kes salgaks, et tõelised luuletused säravad neist voorustest.

36 Tegusõna collutulare ei olnud antiikajal kasutusel; Plautusel („Trinummus“, 692) esineb aga sellest tuletatud tegusõna collutulentare („väljaheidetega pritsima“).

37 Peapööritust tekitav (lad k vertiginosus) - ainukasutus antiikautoreil: Plinius „Looduslugu“, 23, 59.

38 Kreeka mütoloogias Hypnose poeg, unenäojumal.

39 Samosel oli sündinud filosoof Pythagoras.

40 Horatius „Luulekunstist“ 5 (RKA 1971: 342, tlk Ülo Torpats). 
Meenutagem niisiis, meenutagem Luule esimesi lätteid - toob see ju meie asjas palju kasu. Esmast luuletuste loomise tava ei tule tagasi viia ei Linusele, ${ }^{41}$ ei Orpheusele ${ }^{42}$ ega teistele, keda tõi esile taeva poole kulmu kortsutav Kreekamaa, vaid pühadele meestele, kes polnud täidetud mitte Hippokrene vedelikust, ${ }^{43}$ Pythia hullusest, ${ }^{44}$ vaid Pühast Vaimust. Nii nagu teistegi teaduste tundmine, nii valgus ka Luulekunsti austamine rahvaste sekka juutidelt. Oli ju Mooses see, kes pärast Egiptuse orjapõlve ahelate murdmist, Punase mere sügavike kuivamist israeliitide läbilaskmiseks, vaenlaste uppumist ning teekonna jätkumist rõõmu, kiituse, imetluse, hämmastuse ja peaaegu jumaliku sisenduse mõjul vallandas pärast ennekuulmatut imetegu ennekuulmatut keelt kasutades äkitselt värsimõõtu valatud sõnad. ${ }^{45}$ Esimesena laulis ta hümni tõelisele Jumalale, kellest võib lugeda igas ajaloos, ja vajutas mitte üksnes enda, vaid kõigi kohalviibijate ja järeltulijategi südamesse teenituima tänu märgi. Kes suudaks väärikalt ülistada tema lahkumisluuletust, peaaegu luigelaulu? Rauast peab olema see, keda ei liiguta selline stiiliülevus ja argumentide kaalukus ja tunnete jõulisus, ja kes ei kohku eemale sellisest nurjatusest ja kangekaelsusest, mida ülipüha Luuletaja kurvana oma rahvale ennustas. Järeltulev põlv loeb kuulsusrikka eelkäija jälgi ja ei hakka minagi koostama kõigi sarnaste usklike kataloogi. Meile piisab kahest valitsejast. Vaadelgem Taavetit, kuningaist ja laulikest õnnelikemat. Kes usklikest ei kannaks tema ülevaid psalme, mis on täidetud ohete, kaebuste, üleskutsete, ähvarduste, õnnitluste, tänuavalduste, ennustuste ja lõpuks ka mõistatuslike saladustega isegi sügavaimas südame peidupaigas kui need, mis olid pandud Aleksandri ${ }^{46}$ laekasse? Kes vahetaks need välja tuhande Hesiodose, Pindarose, Marode, Ovidiuste omade vastu? ${ }^{47}$ Kes kreeklastest, kes roomlastest on andnud

41 Linus (kr Linos) - Apolloni poeg, kes õpetas Heraklesele muusikat, kuid hukkus noomimise peale vihastunud Heraklese kitaarahoobist.

42 Orpheus - müütiline kreeka laulik, pärit Traakiast. Tema laul olevat liigutanud isegi taimi, loomi ja allilma elanikke.

43 Hippokrene - allikas Kreekas Helikoni mäel, mis olevat tekkinud Pegasose kabjalöögist ja millest said juua muusad.

44 Pythia - luulekunsti jumala Apolloni preestrinna Delfis, kes tõi eeterlikest aurudest inspireerituna kuuldavale ennustusi.

455 Mo: 32,1-43.

46 Aleksander Suur olevat isegi sõjaretkedel kandnud laekaga kaasas Homerose eeposte kirjarulle.

47 Hesiodos - esimene kreeka poeet, kelle kohta on eluloolisi andmeid, elas umbes 700 ekr ning kirjutas heksameetris õpetusluulet („Tööd ja päevad“, „Jumalate põlvnemisest“). Esimene Euroopa luuletaja, kes rääkis luuletamisest kui oma kutsumusest ja kui muusade annist. Pindaros - kreeka koorilüürika autor 6/5. sajandil eKr, luuletas ülekreekaliste võistlusmängude võitjate auks võidulaule, väljendades neis kreekalikke väärtusideaale. Publius Vergilius Maro - 1. sajandil eKr tegutsenud Rooma eepik, Rooma rahvuseepose „Aeneis“ autor. Publius Ovidius Naso - 1. saj eKr / 1. saj pKr elanud Rooma eleegiline ja didaktiline poeet, voolava ja perfektse ladina heksameetri looja. 
sellest ülitarga poja ülemlaulust poeetilisemat, ehkki paljud näevad vaeva, loomaks ülistavat luulet ${ }^{48}$ ? Kes oleks andekam kaunistuste, metafooride, võrdluste vaimukuse poolest - nimelt nendele rajab poeetide hulk kogu lootuse heakskiidu, loorberipärja ja monumentide saamiseks? Ehkki see ülijumalik luuletus kaotab teistesse keeltesse valamisel nii mõndagi oma haprast ilust heebrea keele erilise keerukuse tõttu, mida ei ole võimalik teistes keeltes jäljendada (nagu on pärast Siirakit märkinud ka „Juudi muinsuste“ autor, ${ }^{49}$ kui õigesti mäletan). Vaikin selle võrreldamatu teose salapärasusest, vaikin muustki, mis hoolimata oma suurejoonelisusest näivad siiski õiglaselt kauaks varjatuks jäävat. Selle püha luule väärikus ja kasulikkus on leidnud erakordset tunnustust, kui selle peale mõelda, sest selle erakordse kingituse LOOJAKS ja ANDJAKS on JUMAL. Väljendades seda sõnadega, annab see mees tunnistust, et ta järgis JUMALA südant, kui ta hüüdis mitte tühiselt hoobeldes (nagu paganlike poeetide ennasttäis salgal tavaks), vaid alandlikemas tänutundes, meie selguses: MINU KAUDU KÕNELES JUMALA VAIM! See on meie Luule tõeline päritolu, ehtne kiitus. Sest kui keegi on kübetki veendunud, et selleks oli või võis olla kas Apollon või muusad või mingi muu barbaarne jumalus, siis on ta täiesti eksiteel: luulealase rumaluse tõttu riputab ta petliku eefeupärja, eksitava silmapette ${ }^{50}$ ühes pealiskirjaga oma tühistele veinidele, ütleksin täpsemalt: ta proovib ebapuhaste deemonite ülbusega peituda ise nende maskide taha, võtta endale au, mis kuulub ainult JUMALALE. Seetõttu olen endamisi tihti imestanud, miks nii mõnigi kristlik poeet ei usalda oma tõsiseid, erudeeritud luuletusi käibesse lasta, kui need ei kriiska sel moel järjekindlalt väljamõeldud jumaluste ${ }^{51}$ tühiseid nimesid justkui rohutirtsud suvepäevil oma laule. Usu mind, õppiv noorsugu, palju võimsamad on need [jumalad], kes sinu luuletustele kaalu ja meeldivust lisavad, kui Phoebus ja pieriidid ja eumeniidid ja Kerberus $^{52}$ ja paganate ülejäänud deliiriumid, olgu neid siis või kuussada. Ja ma ei annaks mitte kübetki (kasutades Plautuse sõna) ${ }^{53}$ luuletuse eest, mis ei lisa ülekullatud vaagnal mõttetute sõnade pompöössele tühisusele mingit tõelist õpetust. Seetõttu kui sa loed ladina ja kreeka poeete (mõnikord laskume me nendenigi), selleks et teada, kuidas sa oma teoseid ekslikult täita võid, kuidas Pallas hüppas Jupiteri peast välgulöögi mõjul esile, kuidas

48 Ülistav (lad k erasticus) - ilmselt tuletis kreeka laensõnast erastes 'austaja, armastaja', antiiksetes ladinakeelsetes allikates ei esine, ka varauusaegsetes leksikograafilistes teostes pole õnnestunud ühtki esinemust leida.

49 Viide 1. sajandi pKr juudi ajaloolasele Josephus Flaviusele.

50 Silmapete (oculiferium) - varauusaegne sõnamoodustis, mida antiikajal ei tuntud.

51 Väljamõeldud jumalus (lad.k. deaster) - kristlik tuletis sõnast deus, klassikalises keeles ei esine.

52 Phoebus - Apollo lisanimi; pieriidid - muusade rööpnimi Pieria paikkonna ja Pierioni mäe nime järgi; eumeniidid - kättemaksujumalannad, kes muutusid õnne- ja viljakuse toojateks; Kerberos - mitmepäine koer allilma väravas.

53 Kübe (lad k titivillitium ) - sõna ainuesinemus Rooma kirjanduses on Plautuse komöödas „Casinaria“, v 347. 
Vulcanus lootena hauti välja isa reiest, kuidas Proserpina rööviti, kuidas Mars ja Venus tabati, siis peab su juures olema manitseja, mõni Lukianos, ${ }^{54}$ kes näeks vaeva sinu tagasikutsumisega selle pöörase plaani juurest õigel ajal, seni kuni see peakolu on veel ravitav. Ülejäänud asjad on palju tähtsamad ja kõrgemad, mida ma käsin sul poeete lugedes välja selgitada, jälgida ja tulevase kasutamise tarvis tallele panna. Jumalike asjade mõistmiseks kogu kahe käega ja rikkalikult meie ajastu puhtamatelt teoloogidelt, seevastu mitte midagi või siis väheke paganlikelt poeetidelt: ehkki on neid, kes koos Eusebiosega arvavad, et Vergilius olevat ennustanud Kristuse peatset saabumist, ${ }^{55}$ kes väidavad, et Sibüll ${ }^{56}$ ei saanud oma ennustusi võtta mujalt kui ainsalt tõeliselt Jumalalt, hülgan ma selle jumalavallatu, kindlasti ohtliku arvamuse ning palun ja manitsen ka suursuguseid noormehi, et nad hoiduksid nagu mürgist sellest varjatud ebajumalakummardamisest ja vabameelsest eksitusest, mille põhimõtted levisid enne ristiusu tulekut.

Samas ma kinnitan siiski, et ma kavatsen teie ja minu enda soovil põhjalikult näidata, et paganlikest poeetidest on palju kasu kõikide ilmaasjade tundmisel, et nad ôhutavad tõhusalt püüdlema vooruse poole, mida tuleb teha nii eraviisiliselt kui ka avalikkuses; et nad valavad justkui mingil salaväel, justkui mingite kanalite kaudu profaansele kõnekunstile teatavat suursugust vaimu ja toda meeldivust, mis kõikjal kuulsusrikkalt triumfeerib; et luulekunsti õpinguil on silmnähtavaim kasu ja veetlevaim meeldivus. Sest kas me peaks tõesti arvama, et luuletaja suudab oma ülesande lahendada müütidega, isegi kui need on loodud kritiseerimiseks? See pole üldse mitte tema tõeline eesmärk. Ta läkitab teadmatuse raske haiguse käes vaevlevatele hingedele kasutoovaid rohtusid, ${ }^{57}$ ent kuna need võivad tema teada iiveldust tekitada, mahendab ta nende kibedust allegooriate, apoloogiate, võrdluste, kirjelduste ja muude kaunistuste seesamiga, nõnda et nende talumine oleks väljakannatatav ja et neid lausa soovitaks alla neelata. Usaldusväärsust lisavad sellele asjale need, mida luiskas Orpheuse ja Amphioni kohta järeltulev põlv. Kelle sõnadega edastaksin seda paremini kui poeedi omadega? Ta on öelnud nii:

Orpheus, preesterlik tõlk, püha taevaste tahtmise tundja, võõrutas metslaste soo tapatöist ning roojasest toidust:

54 Lukianos - kreeka keeles kirjutanud satiirik 2. sajandil pKr, taunis oma satiirides mh ebausku ja põhjendamatut imede uskumist.

55 Neljandas ekloogis, mille Vergilius kirjutas ligi 40 aastat enne Kristuse sündi, nähakse värssides 44-52 ettekuulutust Kristuse sünniks. Eusebios - 3/4. sajandi õpetlane, Caesarea piiskop, kes kirjutas keiser Constantinus I soosikuna esimese „Kiriku ajaloo“, milles käsitles perioodi ristiusu tekkest aastani 324 pKr.

56 Sibüll - naisennustaja, kes kuulutas jumaliku inspiratsiooni mõjul tulevikku.

57 Kasutoov (lad k proficuus) - vanaladina perioodil kasutusel olnud omadussõna. 

siit siis jutt, et ta teeb lõvid taltsaks ja raevused tiigrid; käib veel jutt, et ka Amphion, kes rajas linnuse Teebas, liigutas kaljusid kord, oma lüüraga juhtides leebeil palveil neid, kuhu tahtis ta meel. Oli tarkuseks muiste tõmmata piir ühis- ning eraasjades, vaimses ja maises, [---]
linnasid kerkima panna ja Iõigata seadused puusse Sel moel endale au ning kuulsuse said ülemaised lauljad ja laul. ${ }^{58}$

Niisiis võtsid poeedid muiste enda peale ka filosoofiameti või sõnastades selgemalt: olid ise filosoofid. Öeldut kinnitab ülimalt autoriteetne mees Maximos Tyrosest ${ }^{59}$ oma õpetusega: luulekunst on filosoofia - ajalt muistne, esitusviisilt värsistatud, sisult väljamõeldis. Temaga samal arvamusel on ka Platon (teisal küll luuletajate karm piitsutaja), kellelt pigistas tõe kiirgav selgus vastupuiklemisest hoolimata lõpuks dialoogis „Lysis“ välja auväärseima tõenduse: „Luuletajad on filosoofia isad ja juhid.“60 Sedasama mõistis Aristotelese juhiste põhjal Aleksander Suur, kes vedas Homerost kaasa sõjasarvede hüüu, väelaagrite ja lausa helkivate relvade kõmina keskele, ja Alkibiades, kui andis kõrvakiilu õpetajale, kes keelas tal sama poeedi teoseid omamast. ${ }^{61}$ Kuivorrd suurejoonelised on suure Scaligeri ${ }^{62}$ vaated kogu luulekunstile? Eetika ja poliitika alalgi saame me paremaks ja targemaks ühestainsast Vergiliuse lugemisest kui kõikide filosoofide õpetustest kokku. Kui kõrgelt hindame seda, et poeedid ülistavad tänulikes kiidulauludes mitte üksnes kangelasi ja teisi tsiviil- ja militaarvaldkonnas väljapaistvalt teenekaid mehi ja kannavad nende väljapaistvaid tegusid igavikutemplisse, vaid et nad kannustavad selle abil ülimal määral ka järelpõlve järgima samasugust vooruslikkust ja kuulsust. Kui palju leegitses Makedoonia kuningliku nooruki63 põues leeke, kui ta

58 Horatius „Luulekunstist“, v 391-397, 399-401 (RKA 1971: 350, tlk Ülo Torpats).

59 Maximos Tyrosest - antiikne kõnemees ja filosoof 2. sajandil pKr, põhjendas oma arutlustes pealkirjaga „Dialexeis“ Homerose allegoorilise tõlgendamise vajadust ning selgitas Platonile vastandudes muistsete luuletajate samaväärsust filosoofidega.

60 Platon „Lysis“, 214a.

61 Alkibiades - Ateena riigimees ja väejuht 5. sajandil eKr. Alkibiadese õpetajaks oli mõnda aega Sokrates.

62 Julius Caesar Scaliger (1484-1558) - Itaalia päritolu humanist, postuumselt 1561 ilmus tema mõjukas luulekunsti käsiraamat „Seitse raamatut luulekunstist“ („Poetices libri septem“).

63 S.t Aleksander Suur. 
Sigeionis, ${ }^{64}$ Achilleuse haua juures ütles (olgugi et ta vedas endaga ajalookirjanike salku) ${ }^{65}$ : „Oo õnnis nooruk, kes sa leidsid oma vapruse ülistajaks Homerose!“66 Sest millises hinnas olid roomlaste kõneosavaima konsuli juures alati poeedid, õpivad tänapäeval isegi koolipoisid tollest õpetatud kõnest Aulus Liciniuse kaitseks. Ent miks peatun neil, mida kõik niigi teavad, milles keegi ei kahtle, kui ta just täiesti hull pole? Pigem sellest, ent lühidalt. Luuletajate hoolikas lugemine toob ülimal määral kasu mitte ainult neile, kes ise kunagi püüavad midagi sarnast luua ja plaanivad pälvida harituima vaimu kiitust, mis ainsana pidi muutma mehiseks ja aitama ületada kõik raskused, vaid rohkem isegi kogu proosavormis kõnekunsti jaoks. Kuulakem veelkord selle Rooma Demosthenese ${ }^{67}$ õilsat ülestunnistust, kui ta ütleb: „Neist (poeetika)õpinguist võrsus minu avalik kõnepidamisoskus." Ta laulis ühes Tacituse või Quintilianuse „Dialoogiga kõnemeestest“ (mõlemad on teose [autorsuse] väärilised), kui kinnitas, et kõik kõnekunsti lätted ja saladused on peidus poeetide saludes ja hiites. ${ }^{68}$ Samamoodi kiidavad luuletajaid targim kõnemeestest Fabius Quintilianus, ${ }^{69}$ teravmeelseim filosoofidest Lukianos. ${ }^{70}$ Nende autoriteeti ja arvamusi ei kiida ma mitte selle pärast, et mind uskuma jäädaks - poeetide köited tuleb läbi töötada sel ainsal eesmärgil, et nende sõnu saaks vajadusel kasutada. Tunnistan, et see pole tähtsusetu - näeme me ju seda kõikjal kinnitamas ja tõestamas küpseid proosavormis kirjutisi, mis tsiteerivad luuletajate mõtteid lausa selleni, et isegi APOSTEL ei vältinud neid sobivas kohas. ${ }^{71}$

Siiski on mõned teised küsimused hulga põletavamad. Üldlevinult nimetatakse kõnemehe nelja ülesandena leida sobiv aines, ülesehitus, stiil, esitusviis, ent nende kõigi seas pole ühtki, mis ei saaks abi luuletajate imetlusväärt suurelt abistavalt salgalt. Sest kes oleks

64 Sigeion (lad k Sigeum) - kreeka linn Väike-Aasia loodeosas, Trooja lähedal Skamanderi jõe suudmealal, kus olevat vastavalt Homerosele („Odysseia“, 24, 80-84) asunud Achilleuse haud. Achilleuse hauaküngas olevat olnud näha ka merelt tulles. Alates 5. sajandist eKr muutus paik kultuse- ja palverännu sihtkohaks, mida väidetavalt külastasid ka pärslased, Aleksander Suur jt (Arrianus „Anabasis Alexandri“, 1, 12, 1; Cicero „Poeet Archiase kaitseks“, 24; Plutarchos „Alexander“, 72 jm).

65 S.o ajalookirjanike teoseid.

66 Tsitaat M. Tullius Cicero kõnest „Poeet Archiase kaitseks“, 24 (62 eKr). Kõne ajendiks oli kaebus Antiookias sündinud kreeka poeedi Archiase (rooma nimega Aulus Liciniuse) Rooma kodakondsuse illegaalsusest; sõltuvalt kaitstava luuletajastaatusest on kõne keskseks teemaks poeesia ja vaimukultuuri väärtus.

67 S.o Cicero. Kaudtsitaat teosest „Poeet Archiase kaitseks“, 13.

68 Tänapäeval omistatakse „Dialoog kõnemeestest“ Tacitusele, poeetide saludest ja hiitest vt 12, 1-2.

69 Marcus Fabius Quintilianus - Rooma kõnekunstiõpetaja 1. saj pKr, 12 raamatust koosneva „Kõnekunstiõpetuse“ autor.

70 Lukianos - vt märkus 53.

71 Apostel Pauluse Lukianose-tsitaatide kohta vt nt Lindemann 2008. 
kunagi olnud poeetidest viljakam kõiksugu ainese leidmise rikkuselt? Nad ei ole jätnud puutumata midagi, mida inimoskused suudavad välmida! Sageli on nad läinud isegi kaugemale, nii et filosoofid, jõukuse ${ }^{72}$ õpetajad ja juhid, olles ülimeeldivate inimeste imetlusväärsest andest meelitatud, heidavad neile järjepidevalt ette, et neile olevat abiks kaitsevaimud, taevane hingus, jumalik tunnetus. Nii nagu kogu kommete ja tunnete käsitlus on poeetide väljamõeldis, nõnda on see jõudnud kõnepultidesse, kohtutesse, mujalegi. Kunagi keelati see tollel suursuguseimal Athena areopaagil, kuid kutsuti siis uuesti tagasi ${ }^{73}$ ning seda kasutati Kreeka ja Rooma kõnemeeste poolt niivõrd, et paljudes kahtlastes asjades sai sellest tähtsaim tõendus, mida Cicero paljudes kohtades tunnistab. Teiseks kasutasid poeedid esimesena kunstipärast ülesehitust, krypsis' ${ }^{74}$ ja võrdlusi, vastavalt kõnemehe järgmisele ülesandele. Päev kuluks mul käest, kui ma tahaksin käsitleda kõiki võtteid, mida andekaimad inimesed on siinkohal rakendanud ja demonstreerinud. Kiirustan stiilivõtete juurde, mille puhul kõik kiidu- ja imetlusväärne, mida kõnemehed üles näitavad, on laenuks võetud luuletajatelt. Neile on nad võlgu sõnavaliku, puhtuse, sära ja selguse, nende valgusest on süüdatud troopide ja figuuride mitmekesisus. Nemad on esimesed ja tõelised kompositsiooniarhitektid. Jätan kõnelemata vahelduva sõnajärje variatiivsusest, milles jällegi tuleb enim poeete imetleda; jätan kõnelemata perioodide ulatusest ja perifraasidest. Samuti loevad poeedid ilmseima õigustusega oma pärusmaaks junktuure. ${ }^{75}$ Kes grammatikuist, kes kriitikuist on iialgi hoolsaimagi kõnemehe junktuuri niivõrd imetlenud, niivõrd austanud, kui neid ülituntud ja lausa kuldseid Vergiliuse värsse?

Kapates kiirete kapjade plaks rabas murduvat mulda. ${ }^{76}$

Võik, jube, tülgas, hiiglaslik roist, sõge, silmitu julmur. ${ }^{77}$

Või peaaegu Iõputult teisigi selliseid värsse. Sest kui prooviksin rääkida sellestki, mil moel kõnemehed on poeetidelt omandiõigusega endale tirinud rütmi, mitte küll täielikult,

\section{Jõukus, rikkus (kr k euporia).}

73 Nt Lukianose („Anacharsis“, 19) sõnul tohtis Ateena Areopaagil kohtukõnet pidades edastada sissejuhatavalt üksnes juhtunu sisu ega kasutada keerukaid retoorilisi võtteid, et vältida kohtunike meelestamist endale sobivas suunas.

74 Aristotelesel („Toopika“, „Analüütika“ jm) kasutatud termin tähistamaks varjatud, salapärast või vihjelist esitusmeetodit, mille Petrus Ramus vastandas varauusajal oma selgust taotlevale binaarsele esitusmeetodile.

75 Junktuur (lad k callida iunctura) - ootamatu, üllatav või teravmeelne sõnaühend.

76 Vergilius „Aeneis“, 8, 596: quadrupedante putrem sonitu quatit ungula campum. TIk Ants Oras.

77 Vergilius „Aeneis“, 3, 658: Monstrum horrendum, informe, ingens, cui lumen ademptum. TIk Ants Oras. 
kuid võtnud algselt võõra asja siiski ühisomandisse ja andnud sellele ise nime, siis tuleks paljude suhtes olla karm. Rooma kõnemeeste korüfee on andnud selle kohta lühikese selgituse, öeldes: „Luuletajad on esitanud küsimuse, mis on see, mille poolest nad erinevad kõnemeestest. Varem näis, et eelkõige rütmi ja värsi poolest. Ent nüüd on hakanud rütm ka kõnemeeste seas levima. Sest kui miskigi meie kõrvus kõlab veidigi rütmiliselt, ehkki pole värss, kutsutakse seda rütmiks ja kreeka keeli nimetatakse seda ' $P v \theta \mu o \varsigma^{7}{ }^{78} \mathrm{Ja}$ ilmse hoolikuse tõttu rütmistamisel ongi Herodotose ja Thukydidese ajalugu nimetatud kauniks luuleks, Platoni oma aga luuleliseks kõnekunstiks. ${ }^{79}$ Loodan, et keegi ei keera selle väite tähendust ümber nii, et arvaks mind proosa- ja luulestiili segavat - see pole vähimalgi määral mu seisukoht. Kõige paremini täidab oma kohuseid see kõnemees, kes püüab oma kõnekunsti teha luulekunsti sarnaseks, mitte siiski pildina, nagu kuskil on maininud Plinius Secundus, ${ }^{80}$ vaid nagu tütar on ema sarnane. Jääb veel üle, et nõuaksin esituskunsti esmaõiguse tagastamist poeetidele, kellele see esialgu ainukesena kuulus. Ent nii nagu ma ülejäänud paragrahvides olen lugupidavalt ja õpetatud kuulajate kõrvu säästvalt peaaegu kõike käsitlenud ratsahobuse seljast, ${ }^{81}$ nii ka siin käsi peaaegu kohe maali juurest eemale! ${ }^{82}$ Jäägu need üksikasjad teiseks korraks. Lisan siiski üht, ent see on ülioluline: luulekunsti harrastamine toob imetlemisväärselt suurt kasu keelte arengusse üldiselt. Tahtmata esitada rohkearvulisi põhjendusi, mida leidub tõesti kõikjal, pakub meile tänapäeval meie saksa keelgi kreeka ja ladina keele kõrval tõestuse selle kohta: pärast kaikaga ${ }^{83}$ „keelemeistrite“ ${ }^{44}$ mitmesuguseid piinamisi jõudis ta tänu poeetikareeglite hoolsale silmaspidamisele edukalt suurema sära ja kuulsuseni.

Ent nüüd aitab luulekunsti kasulikkusest, jätkame meeldivusega. Mitte ühtki sõna! Miks võtta käsile asjatu töö? Luuletuste mahedus tungib ju teatava salapärase, kuid seda imetlusväärsemalt meeldivama täiuslikkusega iseenesestki silmisse, kõrvusse, hingesügavustesse.

\footnotetext{
78 Cicero „Kõnemees“, 66, 7 - 67, 4.

79 Cicero „Kõnemees“, 2, 55-57; 62

80 Plinius „Looduslugu“, 37, 15.
}

81 Ratsahobuse seljast (lad k desultorie) - määrsõnana antiikajal ei esinenud, antiigijärgne sõnatuletis.

82 Plinius „Looduslugu“, 35, 80: lugu maalikunstnik Apellesest, kes nähes Protogenest liialt kaua üht maali viimistlevat ja kartes, et maal läheb suurest viimistlemisest pigem halvemaks kui paremaks, olevat hüüdnud: „Käsi maalist eemale!“ (manum de tabula). Vanasõnalise väljendina kasutusel juba antiikajal, näiteks Cicero „Kirjad lähedastele“, 7, 25, 1; Petronius „Satyricon“, 76, 9. Laialdase tuntuse varauusajal tagas esinemus Erasmuse vanasõnakogumikus „Adagia“, 1, 3, 19.

83 Kaikaga, s.o nuia kujuline, nuia moodi taguv, nuia häält tegev (lad k rhopalicus, -a, -um) - kreeka laensõna, ladina keeles kasutusele võetud pärast antiikaega.

84 Keelemeister (lad k magistellus) - pejoratiivne vähendusvorm sõnast magister, näited antiikaegsest kasutusest puuduvad. 
Kõike seda esitleb meile ühekorraga Tullius, ${ }^{85}$ kes oli edukam luule patroonina kui viljelejana, öeldes nõnda: „Luulekunsti viljelemine toidab noorsugu, rõõmustab vanadust, on ehteks edu korral, pakub pelgupaika ja lohutust ebaõnnes, toob rõõmu kodus, pole takistuseks võõrsil, veedab meiega ööd, viibib meiega reisil ja maal." 86 Miks peaks siis imestama, kui arvesse võttes ülipaljusid meie kunsti auavaldusi, meeldivusi, hüvesid, hakkas auväärne antiikaeg tema austajaks, ehtides end selle jumaliku kingitusega? Kui luuletaja nime ei pidanud pühaks ja auväärseks mitte üksnes haritud rahvad, vaid ka harimatud? Kui auväärseima Joonia ja ümberkaudsete saarte linnad püüdsid ülima vaimu- ja väideteväega, et kumbki võiks pidada Homerost kas enda riigi omaks või ennast Homerose omaks, nii et nad pühitsesid talle templeid justkui mõnele pühale jumalusele? Kuulsaimad pealikest, kuningaist, valitsejaist toimetasid ise vaevarikka ühiskondliku kohustusekoorma all muusade pühamutes, saavutades tihti kuulsuse, kuid mõjutasid ja toetasid lahke loomuse ettenägeliku abi ja väsimatu suunamisega pideva harjutamise poole, käsitsemaks osavamalt Apolloni plektronit, ${ }^{87} \mathrm{ka}$ väljavalitud noorukeid, keda nimetatakse juba ammu kasutusele võetud sõnaga poeetideks, soosides neid preemiate, privileegide, austusavaldustega, niivõrd kui nende olukord lubas. Suur oli väärikuse ja kuulsuse erinevus nende sõjavälkude, nii Aitoolia Fulviuse ${ }^{88}$ kui ka [Scipio] Africanus Vanema, ${ }^{89}$ ning Enniuse, ${ }^{90}$ peaaegu lehkava poeedi vahel, kes elas ikka veel tahumatu ajastu ebasoodsais oludes. Ent siiski olid nad kumbki temaga lähedastes ja ülimalt tihedatest sidemetes ning see võrdsus oli talle ülimalt meele järele. Kelle imperaatorlik majesteetlikkus oli üllam Octavianus Augustuse omast? ${ }^{91}$ Eeskätt rõõmustas tema ülihelde kõrgus siiski luuletajate Horatiuse ja Vergiliuse ${ }^{92}$ lähima kaaskonna üle, nii nagu tagasihoid-

85 S.o Marcus Tullius Cicero.

86 Cicero „Poeet Archiase kaitseks“, 16, 12-15.

87 Plektron - keelpillide mängimiseks mõeldud kepike, tuntud kreeklaste juures vähemalt 7. sajandil eKr.

88 Fulvius Aetolicus - õieti Marcus Fulvius Nobilior, kes sai lisanime oma eduka sõjakäigu tõttu Aitooliasse. Ennius oli sellel sõjakäigul Fulviuse saatjaks ning kirjutas sellest hiljem komöödia „Ambracia“.

89 Scipio Africanus Vanem - Rooma väejuht ja riigimees 3/2. saj eKr, lahingute eest Aafrikas sai lisanimeks Africanus. Oli üks paljudest Enniuse soosijaist.

90 Quintus Ennius - Rooma eepik ja draamakirjanik 3/2. sajandil eKr, võttis Rooma luules saturnilise värsimõõdu asemel kasutusele heksameetri.

91 Octavianus Augustus - Rooma esimene keiser, valitses princeps'ina alates Actiumi lahingust 31 eKr kuni aastani 17 pKr, tema ajal jõudis Rooma kultuur nn kuldse ajastuni.

92 Quintus Horatius Flaccus - Rooma lüüriline poeet 1. sajandil eKr; Publius Vergilius Maro - Rooma rahvuseepose „Aeneis" autor (1. sajandil eKr). Mõlemad kuulusid keiser Augustuse aegsesse Maecenase luuletajate ringi. 
likema valitseja mõnus nali sellise saatuse kohta on jõudnud ka ajaloomälestistesse: „Istun kesk pisaraid ja ohkeid“. ${ }^{93}$

Ent miks kutsun surnuaedadest välja võõramaalaste ja ammusurnute vaime, kui meid kutsuvad rõõmsalt andunuimale järgimisele, hardaimale ülistamisele elavate ja mitte mingilgi moel tähtsusetumate näited? Kui ROOTSIMAA TAEVA ÕNNEPÄIKE KARL ${ }^{94}$ lööb praegu paljudes kohtades ohkiva Thalia pilvetaeva üliheldelt selgeks, kui Põhjala kuningriigi helkivaim täht annab heldeimalt valgust sellele kuulajaskonnale ja (ärgu jäägu miskit puudu täiuslikust kuulsusest!) ka minu kui innukaimate alamate seast kaugeima pimedusele? Nimelt seetõttu on minu kõne, mis väldib skolastiliste teravmeelsuste kõverteid ja on seetõttu kohane austuse väljendamiseks, pööratud SINU poole, SILMAPAISTVAIM JA VÄLJAPAISTVAIM KUBERNERIISAND, ÕILSAIM KANGELANE, HELDEIM JA LAHKEIM ISAND JA TOETAJA! Sinu kui minu taastamise algataja arvele tuleb arvata ja kirjutada selle õnneliku edenemise korraldamine harda usu alandlikema märgi all. Selle kuningliku gümnaasiumi muusadki, kõige mitmekesisemate ${ }^{95}$ heategude lausvihmast märjad, mõlgutavad rahulikuna mõttes igikestvat eepost SINU VÄLJAPAISTVAIMA NIME AUKS - mida oleks kohasem teha minulgi, kelle ihatud soovi ületas SINU HELDUS, OO ISAND, täielikult? ${ }^{96}$ Olen alati olnud keeletu ja kui ma midagi öelda söandaksin, siis tunnen selle tühisust. Minu vastuväited, millele SINU VÄLJAPAISTVUSE ARMULIKKUS seadis edukalt vastu tugevad barrikaadid, on kummutatud; tunnistan end nüüd ja igavesti mõistvat, et millal iganes ma vaatlen SINU ARMULISUSE heategusid, jään ma täiesti tummaks. Andesta, ISAND, see vaga hämming, mis ei saada mitte keelt SINU KÕRGEAULISUSE ülistamiseks, vaid köidab oma tühise südame lõpmatus tänutundes alandlikemaks teenistuseks. Täna avad sa innukusele muistse võistlusväljaku humanitaarõpingute tarbeks, mida olen korduvalt lootnud. Kui mul õnnestub sellel väljakul eelkõige SULLE kinnitada oma hoolikust, on see kordaläinud. Kaitse edaspidigi oma armuliku helduse kattega oma andunuimat teenijat; juhi alandlik paluja vastaste noolte alt õnneliku kindluse pühasse varjupaika. Nõnda kasvatagu JUMALIK ARM rahva ja minu rõõmuks SINULGI, ARMULISIM TOETAJA, pikaealisust, auavaldusi, au, õndsust! Sest minu austus ja pühendumus, ehkki need jäävad alatiseks ehtsana püsima, ei suuda siiski iial lõpuni täita

93 Legendaarne keiser Augustuse vastus Has inter lacrimas sedeo et suspiria Caesar („siin istun ma keisrina pisarate ja ohete vahel“), mille ta olevat luuletanud vastuseks Maecenasele, kui too astus sisse keisri juurde ja küsis tolle tervise järele. Ühel pool Augustust olevat istunud pidevalt silmapõletiku tõttu pisaratega hädas olnud poeet Horatius, teisel pool vanadusnõrkusest vaikselt ohkav Vergilius.

94 Karl XI.

95 Mitmekesine (lad k plurifarius) - hilisantiikne omadussõna, mis leidub üksnes hilisantiikse autori Sidoniuse kirjades.

96 Johannes Hörnicki sulest ei ole siiski teada ühtki Karl XI-le pühendatud eepost. 
Iõputut tänamiskohustust. Ja Teiegi, KÕRGEAULISED, AUVÄÄRSEIMAD ja MÕJUKAIMAD MEHED, BÜRGERMEISTRID ja RAEHÄRRAD, selle kuulsusrikka ${ }^{97}$ linna imeteldavad, auväärsed METSEENID ja PATROONID, teilegi tuleb avaldada järgneva kõnetamisega lugupidamist. Nii praegune piduhetk kui ka minu tulevane amet on ülimal määral teiega seotud. Te olete minu kätte andnud osa oma surmajärgsest kuulsusest. Palun praegu südamest, et see pant edeneks märkimisväärselt nii siinses gümnaasiumis kui ka kogu linnas, ega säästa ühtki hoolt, unetuid tunde, vaeva ega higi, püüdlemaks, et Te ei peaks kunagi kahetsema mulle osutatud soosingut ega ühtki heategu. Teidki, AUVÄÄRSEIMAD PATROONID, kellele avaldan siinkohal suurt ja edaspidi veelgi suuremat tänu, palun, et te ikka ja alati ümbritseksite püsiva armastusega oma kohusetundlikku ülistajat, kui vaid leiate ta seda tõeliselt väärivat (andku seda TAEVANE ARM!). Ei luba ju teie jumalakartlikkus ja õiglane meel, oo VÄGA LUGUPEETUD JA KUULSAIMAD PASTORIISANDAD JA PÜHA USU EESTSEISJAD, isegi minu hapral nõrkusel mingil moel soosingu kindlas püsivuses kahelda. Võtke niisiis andunud austaja veelgi hiilgavamalt vastu soosingu ja armastuse loodetud pühamusse, selleks et JUMAL võtaks teid, vaimse lahingu eesvõitlejad, pärast siinse elu ettearvamatuid lahinguid koos kõigi meiega oma paleedesse, ehtides teid mitte tammise, vaid lausa kuldse igavese õndsuse krooniga. Ent Teie, KUULSAIMAD, SILMAPAISTVAIMAD ja ÕPETATUIMAD MEHED, REKTORI- ja INSPEKTORIHÄRRA, PROFESSORIHÄRRAD ja teiegi, ülejäänud meeldivaimad ja armsaimad KOLLEEGID, avage hädasolevale sõbrale vastastikuses ja vajalikus heasoovlikkuses oma põu meeldivateks embusteks, usalduslikuks truuduseks, meelekindlaimaks sõpruseks, siiraimateks teeneteks. Mind on pandud ühes teiega samale laevale, mida teie olete siiani kiiduväärselt juhtinud ja hoolitsenud kord rahulikul, kord heitlevamal merel; käskige mul täita laevasõduri või meremehe rolli, see on minu tagasihoidlikkusele piisav, kui me vaid ühisel sõudel ja ühisel nõul jõuaksime möllaval merel ettejuhtuvate kaljude ja koletiste vahelt õnnelikult plaanitud ühiskondliku kasu sadamasse. OO KUULSAIMAD MEHED, armsaimad SOOSIJAD, vallandage oma üliõilsais südameis läänetuulele avatud purjed ${ }^{98}$ mina olen täiesti ja meelsasti valmis järgima teie kogemuse märguandeid. ${ }^{99}$ Ja lõpuks sina, ÕPPIVA NOORSOO kiiduväärseim kroon, võta vastu see esimene tõend minu armastusest Sinu vastu. Ma palun ja palun tulevikuski sulle siinsamas alguse juures Taevase Armu abi merereisi õnnelikuks edenemiseks. Ent veelgi enam - ma luban ülilahkelt, et ma võtan ülimalt kohusetundlikult tarvitusele kogu jõu sinu edusammude suurendamiseks. Sina aga püüa

97 Kuulsusrikas (lad k famigerabilis) - haruldane sõna antiikses ladina keeles, mida on kasutanud üksnes Varro oma ladina keele alases traktaadis ning hilisantiikne proosakirjanik Apuleius.

98 Läänetuult peeti muistses Roomas ainsaks hea mõjuga tuuleks, mis tõi kaasa kevade ja tärkamise.

99 Märguanne (lad k celeu(s)ma) - kreeka laensõna, tuli kasutusele alles klassikajärgses ladina keeles hilisantiiksetel autoritel (Sidonius, Rutilius Namatianus). 
hoolikalt, nagu siianigi oled teinud enda silmapaistvaks kiituseks ja kasuks, ning vii kuuleka usinusega minugi vaev sihile. Sinu teha on külv, sinu teha on kord ka saak. Ära mõtle mitte niivõrd lühiajalise vaeva raskusele, kuivõrd meeldivaimate viljade tasule. ${ }^{100}$ Mõtle luulekunsti õpingute väärikusele, kasulikkusele, meeldivusele, ja sa ületad kergesti takistuste raskuse, kui sulle peaks selliseid osaks langema. Olgu kõigi sinu tegemiste ja soovide sihiks, milleni kummagi puhul tahad jõuda, jumalik au, sinu enda ja riigi heaolu. Luban, et selleni jõudmiseks ei jää Sul minu pärast iialgi miskit puudu. OLEN RÄÄKINUD.

100 Tasu (lad k redhostimentum) - antiigijärgne tuletis üksnes vanaladina perioodi komöödiakirjanikel kasutatud verbist redhostire. 